\title{
A ALIANÇA ENQUANTO DRAMA: EST/ÉTICA DA MASCULINIDADE NO CONTEXTO DE UMA ECONOMIA AFETIVA UXORILOCAL (GUNA, PANAMÁ)*
}

\author{
Diego Madi Dias
}

A partir da casa de residência, o artigo lança um olhar para os Guna, povo falante de uma língua chibcha e que habita o arquipélago de San Blás, na costa atlântica do Panamá (comarca indígena de Gunayala). ${ }^{1}$ A residência em Gunayala movimenta uma economia doméstica dos pensamentos: os Guna dizem que a pessoa preguiçosa (wiegala) não pensa nos outros (binsaed suli). Ela é considerada sunnasuli - "não é parente de verdade" ou, simplesmente, "malvada". Procuro explorar as consequências da ética da convivialidade guna no que se refere à masculinidade, na medida em que os homens são levados a pensar em sua esposa como condição de fixação e permanência na casa dos afins. O problema da troca é examinado a partir das raízes mitológicas, rituais e sociológicas da uxorilocalidade, permitindo compreender o esforço de consanguinização da afinidade nos termos de um drama residencial: o drama da aliança ou a aliança enquanto drama.

Do ponto de vista formal, sabemos que não faz diferença se são os homens que trocam mulheres ou vice-versa, conforme argumentou Lévi-Strauss (2000) em resposta à crítica feminista relativa à circulação de mulheres. Uma teoria indiferente aos afetos, contudo, será necessariamente alheia ao modo como os próprios Guna concebem o parentesco. O parente verdadeiro (sunna) é aquele que, através dos produtos do seu trabalho, "demonstra" (oyoged) o pensamento em benefício dos outros. No contexto de interação corresidente, observei que o imperativo da troca é vivido a partir de expectativas e intenções em torno da perda, da separação e da circulação de recursos masculinos, cujo potencial produtivo será transferido para outra unidade de residência.

Hirschfeld e Howe (1981:320, tradução minha) afirmaram que "a restrição de mobilidade das mulheres constitui um elemento essencial da sua subordinação entre os Kuna". Os autores consideram que as regras que valem para as mulheres (ficar em casa) constituem o motivo de sua subordinação, enquanto as regras que valem para os homens (sair de casa) estão na origem 
do seu prestígio. Trata-se de uma percepção bastante comum à produção etnológica retomada no período pós-guerra e realizada nas últimas décadas do século XX. O contexto intelectual coincide com a gestação e o surgimento da segunda onda do pensamento feminista, que supunha a "subordinação universal das mulheres" a partir da célebre equação < homem : cultura :: mulher : natureza > (Ortner 1974). Joanna Overing chamou a atenção para esse procedimento metodológico nas análises de gênero, espécie de "jogo de perder" (catch 22) que retroalimenta as noções euro-americanas de poder e autoridade como relativas à esfera política e ao espaço público. Para os autores da dominação masculina, "a cultura e as regras sociais constrangem as mulheres, mas não os homens" (Overing 1986:140, tradução minha).

Muitas questões colocadas por Overing nas últimas décadas foram sintetizadas recentemente em sua reflexão sobre a filosofia amazônica de concretização das virtudes: "o verdadeiro poder corresponde à capacidade estética de viver junto de maneira segura e criativa" (Overing 2012:4, tradução minha). A casa guna é o espaço em que a ideologia de parentesco se realiza: é onde se pode efetivamente "viver junto" ou "sentir-se junto" (bulagwa iddoged, também traduzido por "compartilhar"). Margherita Margiotti $(2010,2011)$ foi a primeira a olhar para a socialidade guna desde a casa de residência. Sua abordagem se mostrou capaz de proporcionar novas interpretações sobre a vida em Gunayala. Seguindo essa mesma direção, procuro considerar o espaço doméstico como contexto privilegiado de análise, a casa como estrutura material para onde convergem as trocas comunicativas.

Assumindo uma perspectiva residencial para a análise da subjetivação de gênero e parentesco, eu pude enfim repensar a relação dos homens com o exterior produtivo. ${ }^{2}$ A condição masculina, geralmente descrita nos termos de um privilégio (em função do critério de "mobilidade"), será discutida em função de uma filosofia guna da Ética, isto é, em relação ao imperativo moral que corresponde ao ideal do bom pescador - sair de casa: sair para pescar, sair para casar. A perda e a separação relativa ao filho homem (massered), cujos laços de parentesco serão substituídos em função da dinâmica uxorilocal de residência, revelam um certo "ethos matrimonial", isto é, a ênfase afetiva (Bateson 1936) a partir da qual se vive a aliança. Considerando o ideal de masculinidade como pano de fundo, meu objetivo é ressaltar a interação entre mulheres afins em torno de Ego masculino como "estrutura afetiva elementar" do parentesco guna. 


\section{A captura das filhas das estrelas: origem dos cantos de Nadili ${ }^{3}$}

Houve um tempo em que os homens estavam em maioria, quase não havia mulheres. Na floresta de Darién vivia um casal com seus quatro filhos homens. Todos os dias, o pai lhes preparava manisuar ${ }^{4}$ para que se tornassem fortes e bem dispostos para o trabalho. O tempo passava e os meninos cresciam: trabalhavam no campo e tinham uma grande plantação de bananas; tornaram-se exímios caçadores de porcos selvagens. Traziam comida para casa em abundância e todas as mulheres solteiras queriam se casar com eles.

Mas os irmãos não se casavam. Em segredo, a mãe lhes preparava banhos terapêuticos para mantê-los desinteressados pelas mulheres. Com a continuidade do tratamento administrado pela mãe, uma verdadeira aversão por mulheres se desenvolveu. Os rapazes passaram a considerar sua própria mãe repulsiva. O cheiro insuportável da mãe tinha um efeito sufocante e os irmãos não conseguiam mais comer o que ela preparava.

Eles pensaram muito e decidiram ir embora. Viajaram por quatro dias pela floresta e construíram uma casa nas margens de um rio distante. Durante os meses iniciais, trabalharam muito para se estabelecer ali. Cultivavam inhame em abundância e obtinham carne de caça em grandes quantidades, de maneira que o couro retirado dos animais passou a obstruir o rio.

Certo dia, ao voltarem com um carregamento de bananas, perceberam que a casa estava perfeitamente arrumada. Viram suas roupas limpas. Viram madun 5 e viram a comida preparada. Um pedaço de carne de caça estava faltando. Os irmãos sentiram o cheiro repugnante de sua mãe e concluíram que ela havia estado ali. Eles pensaram muito e decidiram partir novamente: caminharam por mais dois dias e construíram uma nova casa ainda mais longe, nas cabeceiras do rio. A mãe lamentou mais uma vez a perda de seus filhos.

Em sua nova casa, os irmãos acreditavam ter despistado sua mãe para sempre. Até que um dia, chegando de uma expedição de caça, encontraram novamente a casa arrumada. Dessa vez, uma fragrância agradável perfumava o ambiente. Viram suas roupas limpas. Viram madun e viram a comida preparada. Havia sementes de algodão dispersas pelo chão. Os rapazes discutiram e resolveram que um deles ficaria em casa para ver o que acontecia.

Na manhã seguinte, os mais velhos saíram para o trabalho enquanto o irmão mais novo se escondeu em cima de uma grande árvore próxima a casa. Após algum tempo espiando, ele ouviu um ruído que vinha do alto. Olhou para o céu e sua visão foi ofuscada pelo brilho intenso do ouro. Um disco dourado se 
aproximou e aterrissou em frente a casa. Quatro lindas irmãs surgiram do disco voador. Elas entraram na casa e se puseram a trabalhar: prepararam madun, cozinharam a carne, coletaram água no rio, lavaram as roupas, varreram a casa. Ao final da tarde, cada uma escolheu a rede que correspondia ao seu futuro marido. Elas queriam se casar. Descansaram, separando sementes de algodão, até que o disco de ouro regressou para buscá-las.

De volta a casa, os três irmãos estavam curiosos para saber o que tinha acontecido. Após ouvirem o relato do mais novo, eles não podiam acreditar. Os rapazes discutiram e resolveram que o irmão mais velho ficaria em casa para confirmar a história. No dia seguinte, enquanto ele observava de longe, as moças voltaram e repetiram a sequência de atividades domésticas. O irmão mais novo estava falando a verdade.

Permaneceram todos em casa na manhã que seguiu, com o objetivo de capturar as filhas das estrelas. Passaram o dia escondidos, observando as irmãs que trabalhavam. No momento em que elas se deitaram para descansar, os rapazes entraram na casa rapidamente, cada um capturando a mulher que ocupava sua rede. Mas as moças eram muito fortes e três delas conseguiram escapar. Maninadili, Igwanadili e Inanadili entraram rapidamente no disco de ouro, que já esperava no pátio exterior a casa. O mais jovem ainda lutava com Olonadili quando o disco voador partiu, tendo conseguido capturá-la.

Nos primeiros dias que se passaram, o irmão mais novo ficou em casa para impedir que Olonadili fugisse. Mas ela já tinha se acostumado com o cheiro dele e não tentaria mais fugir. Olonadili contou que as quatro irmãs pretendiam se casar com os rapazes. Elas fugiram porque ficaram assustadas. Os irmãos discutiram e resolveram que Olonadili se casaria com o mais velho, mas ela não concordou. Casou-se com o irmão mais novo, conforme sua vontade.

Os rapazes voltaram para sua aldeia natal com Olonadili, que engravidou e deu à luz uma menina. Todos os dias, ela cantava para acalmar sua filha:

Quando você for grande,

Ajudará sua mãe a buscar água no rio

Agora você só pensa em chorar

Por que você está chorando?

Eu estou aqui balançando a sua rede

Eu estou cantando e tocando o maracá

Seu pai está longe, pensando em você

Seu pai está trabalhando para você 
As vizinhas de Olonadili ouviam suas canções e começaram a cantar para as suas crianças também. Após alguns meses, a filha de Olonadili ficou muito doente e morreu. Ela foi morar com suas tias, filhas das estrelas.

Olonadili cantava e chorava ao mesmo tempo:

Você foi embora e eu fiquei pensando

Eu fiquei pensando muito em meu coração

Quando a chuva estava forte, seu pai saía para trabalhar

Seu pai semeou milho e cacau para você

Agora você não pensa em sua família

Todas as noites, antes de dormir, eu vou pensar em seu nome

As mulheres que escutavam Olonadili se entristeceram com ela... começaram a cantar seu choro também.

Olonadili ensinou as mulheres a cantar.

\section{O rapto do noivo}

O mito de Olonadili subverte um aspecto fundamental do sistema de aliança entre os Guna, a saber: a captura ritual do noivo na ocasião da cerimônia de casamento. Os Guna contam que o matrimônio era antigamente negociado pelas famílias e o casal desconhecia as intenções de aliança entre seus pais até o momento do rapto do noivo. Atualmente, o casamento decorre de uma relação espontânea entre aqueles que vão se casar. Contudo, a cerimônia manteve sua forma ritual no sentido de produzir e comunicar uma mudança inesperada nas circunstâncias de parentesco e residência.

Ainda hoje, a surpresa e a relutância do noivo fazem parte da performance ritual por meio de inúmeras tentativas de fuga, acompanhadas por uma plateia eufórica. A festa de casamento é chamada gagalegged (puxar, arrastar). Ela é precedida de duas etapas: ${ }^{6}$

sui amie: escolher o noivo

A expressão sui amie quer dizer "buscar um marido". Entre as qualidades do futuro esposo, ele deve demonstrar disposição para o trabalho e, preferencialmente, ter uma boa canoa. Ele sabe coletar cocos, pescar e consertar as partes de uma casa. Em Mammidub, diz-se de um jovem que não sabe trabalhar que ele ainda está "um pouco cru" (maggi maggi). As mulheres me diziam que o noivo não pode estar cru, ele deve ter sido preparado para que não pensem mal de sua família de origem. 
sui egised: consultar a família do noivo

A primeira acepção para a expressão sui egised é "requerer um marido". Observei que o sucesso de uma relação amorosa depende em grande parte da opinião da mãe do rapaz, que detém uma espécie de "prerrogativa da fala doméstica". No momento em que é consultada, ela se manifesta explicitamente contra ou a favor daquela união. A mãe do noivo avalia sua futura nora em função de características de personalidade, especialmente no que se refere à generosidade ou à avareza. A ponderação é extensiva ao núcleo de mulheres corresidentes em relação à noiva: a melhor maneira de saber se uma moça será generosa ou avarenta é observando o comportamento de sua mãe e de suas tias. Com base nessa observação, pode-se dizer que os Guna atribuem características subjetivas à própria unidade de residência. Em Mammidub, as casas são percebidas como generosas ou sovinas, cujo comportamento decorre da conduta manifestada pelo núcleo de mulheres consanguíneas.

\section{gagalegged: arrastar o noivo}

A cerimônia de casamento tem início quando um grupo de homens surpreende o noivo, normalmente à noite, às vezes no momento em que ele está tomando inna (chicha fuerte, cerveja de milho). ${ }^{7} \mathrm{O}$ casamento não é anunciado previamente e provoca enorme surpresa entre os comuneros. ${ }^{8} \mathrm{O}$ noivo é agarrado e passa a ser carregado pelos braços e pelas pernas. Ele será levado até a casa de sua futura esposa, onde passará a viver com seus afins.

Encenando relutância, o noivo é carregado por seus amigos mais próximos que já estão casados. Eles escolheram previamente um caminho que será percorrido em direção à casa de casamento; um pequeno cortejo os acompanha pelas ruas da aldeia. Os Guna me diziam que é muito importante gritar gagalegged! gagalegged! (arrastando, arrastando) para que todos saibam que aquele homem está se casando, para que todos venham ver.

Chegando à casa da noiva, o rapaz é colocado na rede de sua futura esposa, que o aguarda sentada em um banco no canto da casa. Ela veste suas melhores roupas e tem o rosto coberto com muswe, lenço utilizado na cabeça como parte da indumentária feminina. Alguns entre aqueles que trouxeram o noivo vão em direção à moça enquanto pelo menos um deles deve ficar vigiando para que o rapaz não aproveite para fugir.

O noivo ainda encena sua resistência, provocando muitos risos das pessoas que se aglomeram dentro da casa ou em volta dela, espiando por entre as frestas na parede de cana branca. A moça é então carregada e colocada na mesma rede em que está o rapaz. A tia da noiva traz um pouco de lenha acesa e coloca embaixo da rede, "para que o casal não tenha filhos cegos" (cf. Reverte Coma 1967:13; Prestán 1975:93). 
Os amigos do noivo balançam a rede bem forte, enquanto gritam:

$\begin{aligned} \text { arbae! } & \text { Trabalhar! } \\ \text { sabburbali! } & \text { Ir ao campo! } \\ \text { ua soe! } & \text { Pescar! } \\ \text { negsobed! } & \text { Construir casas! } \\ \text { inmar nudaggo } & \text { Fazer consertos! }\end{aligned}$

Os noivos se levantam e vão até a entrada da casa, onde recebem um banho "para esfriar o corpo": a relação sexual ainda não está autorizada. Em seguida, todos que deixam a casa são também molhados, inclusive os amigos que trouxeram o noivo. Eles torcem suas camisetas enquanto aguardam no quintal pela comida que lhes será oferecida.

A notícia do matrimônio já se espalhou. Ao tomarem conhecimento, os sagla dummagan, chefes da comunidade, dirigem-se à casa da noiva para uma visita. Eles também receberão comida. Os sagla dummagan oferecem ao casal uma sessão de aconselhamento.

\section{unaed: aconselhar o casal ${ }^{9}$}

Agora vocês vão viver juntos. Vocês vão ajudar um ao outro. É muito importante que vocês estejam sempre alegres!

Para ver seu esposo alegre, você não pode ser preguiçosa! Você deve trabalhar para ele: oferecer madun bem cedo, "quando já se pode enxergar, mas ainda não se sente o calor do sol" (waggudar); servir uma boa comida quando ele chegar do trabalho no campo, cansado e com fome; lavar as roupas dele e buscar água para tomarem banho; manter a casa limpa, onde viverão seus filhos.

Para ver sua esposa alegre, você não pode ser preguiçoso! Você deve trabalhar para ela: buscar cocos e bananas da terra para preparar dulemasi [sopa de coco]; trazer muitos peixes para ela dividir em seu nome; consertar o telhado da casa quando houver uma tempestade; cultivar alimentos para os seus filhos e pensar neles para que não tenham fome.

Nos quatro dias seguintes à cerimônia gagalegged, o pai da noiva se dirige à casa natal de seu genro para buscá-lo e reconduzi-lo à casa de casamento, onde o rapaz descansa na rede com sua esposa. Durante esses dias, o noivo pode ainda se esconder e, dessa maneira, o casamento não é consumado. A cada dia, o casal permanece na rede por um pouco mais de tempo: "eles vão se acostumando um ao outro". No quarto dia, eles dormem na mesma rede. Na manhã seguinte, o rapaz vai ao campo com seu sogro: ele deve trazer lenha para a cozinha. Este é o primeiro trabalho que um jovem recém-casado realiza "para sua esposa". Ao voltar do trabalho, o rapaz é recebido pela esposa com uma caneca de madun. Ele entrega suas roupas sujas para que ela lave. A partir de agora, eles viverão juntos (ebogwa). 


\section{A economia doméstica dos pensamentos}

A uxorilocalidade é o padrão de residência pós-marital verificado na maior parte dos casamentos em Gunayala. A tendência uxorilocal foi amplamente documentada e relativamente discutida pela etnografia Guna. Contudo, até hoje a residência não recebeu atenção no sentido de destacar sua centralidade na regulação das afecções de gênero: capacidades gendradas de empreender afeto, pensamento e ação produtiva. ${ }^{10}$

Em sintonia com o material Guna e ameríndio, utilizo o conceito de afecção no sentido proposto na Ética de Spinoza (1677:III, def. 3), retomado em seguida por Bergson (1896) e por Deleuze e Guatarri (1980). ${ }^{11}$ Spinoza desenvolveu a tese do "paralelismo psicofísico", opondo-se ao dualismo entre corpo e alma e contrariando portanto os filósofos da transcendência, como Descartes e Platão. De acordo com esta perspectiva, os "afetos" são definidos como uma variação intensiva ou modulação da potência de ação e de pensamento. Eles implicam tanto as ações quanto as paixões.

No contexto da economia corresidente guna, pode-se afirmar que toda ação produtiva é ao mesmo tempo um ato de amor e memória que se exprime no largo campo semântico do verbo binsaed. Durante o meu trabalho de campo, registrei conotações diversas para essa forma verbal: pensar, lembrar, meditar, refletir, honrar, amar, sofrer (por alguém). Diz-se em Gunayala que os pensamentos de Muu (avó) se dirigem àqueles que precisam comer, em referência ao momento em que a velha senhora separa os pratos de comida, mencionando o nome próprio de cada parente favorecido. Antes de partir para o trabalho no continente, um homem se despede de sua esposa afirmando o compromisso de trazer muitos cocos. Ele pode dizer assim: an be binsaoe, iddosa? (eu vou lembrar de você, escutou?). Um jovem rapaz comparou essa saudação de despedida com a declaração romântica que ele conheceu nas novelas: "eu amo você". Diferente de um sentimento abstrato, o amor se apresenta como uma capacidade social (Boltanski 1990), linguagem e modelo para as relações de intimidade e autoridade (Santos-Granero 1991). 
A chegada de um recém-nascido é muitas vezes anunciada como o nascimento de um pescador ou de uma coletora de água. A preguiça é possivelmente a maior falha de caráter entre os Guna, afinal, quem não produz não tem nada para oferecer aos outros. Aquele que fica com o corpo parado, que não se levanta da rede para trabalhar, não está pensando em sua família. A pessoa preguiçosa (wiegala) é considerada sunnasuli, isto é, "não é parente de verdade" ou, simplesmente, "malvada".

A ênfase empregada aqui deve bastante à perspectiva inaugurada por Joanna Overing $(1991,1999)$ e qualificada por Viveiros de Castro (1996a:190) sob a rubrica "economia moral da intimidade". Entre os Guna, as atividades produtivas engendram relações de parentesco com base na confiança, na solidariedade e na dependência. As tarefas no cotidiano são então percebidas no sentido de uma comunicação ostensiva (Sperber \& Wilson 1986) ou demonstração de afeto.

\section{A mãe e a esposa}

O mito de Olonadili parte de uma situação de escassez de mulheres. Um casal que só tem filhos homens ficará com a casa vazia quando a velhice chegar. ${ }^{12} \mathrm{O}$ nascimento de uma coletora de água (dii baled) é motivo de alegria em San Blas, produzindo uma espécie de socialidade sem perdas: a filha se mantém ligada à casa natal e agrega um genro para esse núcleo de residência. O nascimento de um pescador (ua soe) impõe a perspectiva da separação, tematizada constantemente nas canções de ninar e administrada pela mãe guna na ocasião de consulta à família do noivo (sui egised).

O casamento entre os Guna enfatiza a posição da mãe do noivo como sujeito da troca matrimonial por excelência. A versão do mito apresentada por Guerra e Sánchez (2000:42) conta que o pai dos rapazes teria aceito uma proposta de casamento para seus filhos, mas a mãe deles não concordou:

Yo no he alimentado a mis hijos para que sean esclavos. Yo me sacrifiqué por ellos, y tengo que ser la primera en ser atendida y alimentada por ellos. A mis hijos no los dejo cargar plátanos, zapallos u otoes para otros, sino para mí.

De acordo com a versão de Valdez (apud Chapin 1989:111), enquanto os rapazes cresciam,

la madre comenzó a temer por el día que se fueran de casa, ya que los hombres, al casarse, pasan a las casas de sus señoras. Ella pensó: He criado a mis hijos de manera que sean ayuda para mí y no para otras personas. Quiero que se queden en casa conmigo para siempre. 
O comportamento egoísta da mãe que recusa a aliança desencadeia uma sequência de ações que subvertem os ideais de gênero, parentesco e residência:

(1) renúncia materna quanto à participação na dinâmica de troca matrimonial [ação subversiva original];

(2) evasão masculina sem a realização de aliança;

(3) superprodução contraproducente: o couro retirado dos animais passa a obstruir o rio;

(4) em contexto não corresidente, apropriação indébita de um pedaço de carne de caça por parte da mãe;

(5) captura de uma mulher na rede do seu futuro esposo;

(6) realização virilocal da residência pós-marital.

Por meio de uma sequência de ações subversivas, o mito:

[A] 1,2-coloca problemas que decorrem da falta de relações de afinidade, reforçando o caráter imperativo da aliança entre os Guna;

[B] 3,4-tematiza o trabalho masculino a partir da ausência de esposas e a presença indevida da mãe em contexto não corresidente, chamando a atenção para a regulação feminina da produção;

[C] 5,6-apresenta o casamento e a residência pós-marital por meio de uma inversão quanto aos ideais de gênero, oferecendo um comentário sobre a estética de residência pós-marital.

Com a morte da filha de Olonadili, o mito corrige a situação de residência: a criança vai morar com suas tias, filhas das estrelas, deixando sua mãe com o coração cheio de pensamentos. Em linhas gerais, o mito de Olonadili demonstra que a produção de socialidade tem um custo para as relações consanguíneas de um homem, a partir de sua inscrição em um núcleo interacional que mobiliza a comunicação reiterada entre duas classes de mulheres.

[A] o caráter imperativo da aliança

A interação entre mulheres afins assume a forma de prestações sistemáticas com a oferta de comida no cotidiano. Caminhando pelas ruas de Gunayala, percebemos um trânsito vigoroso de pratos de comida, transportados por moças jovens e oferecidos à casa natal de um homem. Os homens em Mammidub me diziam que uma boa esposa é aquela que pensa na mãe deles, enviando quantidades generosas de comida. Esta observação permite rever aquela outra de Nordenskiöld (1938:31, tradução minha): "os parentes do noivo não recebem nenhuma recompensa por parte da família de sua esposa, ao invés disso, eles perdem uma unidade de força produtiva". 
O fato de uma mulher não pensar na sogra é motivo frequente de tensões conjugais, provocando a queixa e mesmo o choro dos homens embriagados. É comum, contudo, que a sogra avalie o presente com acusações de mesquinharia e não coma o que recebeu da nora. Com a comida proveniente da casa de casamento de seu filho, as mulheres costumam preparar oros sopa, um prato que é considerado uma variação escassa do dulemasi. ${ }^{13}$

Ainda que se refira idealmente às posições de W e M em relação ao Ego masculino, a interação entre mulheres afins é despessoalizada no nível do sistema de atitudes. Uma mulher pode enviar quantidades de comida para a casa natal de seus ZH ou DH corresidentes. Na casa natal, também HZ ou HMZ podem receber e avaliar a dádiva proveniente da casa de casamento. Efetivamente, um homem casado equivale a um nexo de relação entre duas casas ou duas classes de mulheres.

A oferta de comida afirma a interação entre as casas natal e de casamento, que assumem a posição de pessoas morais (Lévi-Strauss 1979, 1984) a partir da de-sujeição do recurso masculino: procedimento que corresponde à técnica de cozimento. Na etapa de escolha do noivo (sui amie), é importante que ele tenha sido preparado por sua família de origem. O rapaz que se casa não pode estar cru (maggi). Também os presentes em direção à casa natal de um homem jamais se apresentam na forma de alimentos crus, mas contêm o investimento afetivo das mulheres que vivem na casa de casamento. As mulheres casadas respondem constantemente à dádiva original em um fluxo de prestações sistemáticas que enfatiza o pensamento ou a lembrança em favor da sogra. A velha senhora, por sua vez, reclama e não come: produz sua própria escassez, talvez como forma de comunicar insatisfação quanto à perda desproporcional de seu filho.

[B] a regulação feminina da produção

A história sobre a origem dos cantos de Nadili contraria uma divisão do trabalho por gênero que esteja estruturada entre a produção da cultura e a reprodução da natureza. Olonadili surge como verdadeira heroína cultural, tendo ensinado as canções de ninar e os cantos funerários como tecnologias poéticas cruciais para os processos de fazer e desfazer pessoas.

Tematizando o trabalho masculino como fonte de recursos "para a casa", as canções de Nadili são contextos de enunciação em que o exterior produtivo aparece subordinado à reprodução do grupo de parentesco. $\mathrm{O}$ problema da regulação produtiva surge inicialmente no episódio em que os rapazes, isolados em grupo masculino, tornam-se extremamente produtivos. Essa passagem demonstra uma superprodução problemática, em que o couro retirado dos animais passa a obstruir o rio. 
A ausência de esposas provoca desequilíbrio na ecologia das relações de gênero, provocando um excesso disruptivo do socius. Em seguida, o episódio em que a mãe rouba um pedaço de carne de caça recoloca o problema da regulação, agora nos termos do direito relativo à produção de um homem. Hirschfeld e Howe (1981:306, tradução minha) sugerem aqui uma subversão operada pelo mito: "normalmente, as mulheres controlam por direito a distribuição de comida, mas aqui a mãe atua como uma ladra, apropriando-se do que pertence aos rapazes". Os autores não notaram que, também na vida cotidiana, a apropriação dos produtos do trabalho de um homem por sua casa natal constitui matéria de acusação de roubo, podendo levar ao fim de um casamento (cf. Margiotti 2010:86). Este ponto foi elaborado por sagla Salcedo em um conselho matrimonial direcionado a um jovem recém-casado (Salcedo apud Howe, Sherzer \& Chapin 1980:66): "Traemos las cosas a la casa y ya no son nuestras. Son de nuestras esposas. Se las das a tu esposa cuando regresas. Ella decidirá que hará con ellas".

No episódio em que a mãe rouba um pedaço de carne de caça, parece importante contextualizar sua relação com os rapazes em função da corresidência descontinuada. Torna-se assim inadequado tratar de "as mulheres guna" de maneira genérica, como "sujeitos de pensamentos e ações" (Lipset 2009:69). Entre os Guna, não há relações sem gênero, mas também não se pode encontrar "gênero puro", exterior ou anterior a uma relação de parentesco atualizada em contexto específico de residência. Em resumo, por meio dos episódios 3 e 4, o mito ensina sobre um regime de diferença que está organizado entre duas classes de mulheres: aquelas consanguíneas e afins em relação a Ego masculino.

Quando um homem chega à aldeia depois do trabalho, ele está em condições de demonstrar que esteve pensando em sua esposa enquanto estava longe. A chegada de um pescador é uma ocasião de demonstração pública de afeto, seriamente investida de expectativa e ansiedade. Um homem fica feliz quando alcança a praia e sua esposa está esperando por ele. Ela aproveita para comentar sobre as condições do mar, às vezes com preocupação. Quando há muitos peixes, o casal se diverte junto e comemora o fato de que aqueles peixes serão distribuídos em nome dele (e nuggined). O retorno de um pescador é vivido por homens e mulheres como um momento de extrema solidariedade conjugal, em que o casal se percebe como uma unidade produtiva no contexto da família extensa. 
[C] a estética de residência pós-marital

Ensinando sobre um regime de diferença que envolve a residência, o mito estabelece os parâmetros de "apreciação da forma adequada" (Strathern 2010:3). Os Guna consideram "feio" quando um homem rompe com a solidariedade conjugal e oferece os produtos do seu trabalho para a casa natal, onde moram suas irmãs e sua mãe (cf. Margiotti 2010:86).

Pode-se dizer que um homem casado deve mesmo "esquecer" as mulheres consanguíneas ou "não pensar" nelas (cf. Margiotti 2010: "forgetting sisters"). Margiotti (2010:165-169) notou que o casamento atua na reconfiguração da memória de parentesco: vivendo com seus afins, um homem pode deixar de chamar suas irmãs pelo nome próprio, passando a se dirigir a elas por "esposa de alguém". A inserção de um rapaz em um novo contexto de residência acontece de modo relativamente hostil: seus laços de solidariedade consanguínea precisam ser desfeitos e substituídos. Trata-se, contudo, de uma passagem contínua, e não discreta: sua incorporação à casa de casamento é precária até que tenha filhos e, inicialmente, ele ainda consome refeições em sua casa natal, para onde retornará em caso de doença grave. ${ }^{14}$

A situação de um homem casado permite evocar a reflexão lévi-straussiana, mas antes ameríndia, sobre a situação de Lua no mito 361 das mitológicas (Lévi-Strauss 2006, vol. 3:38; Gonçalves 2007). Lua tem duas esposas, uma o alimenta bem e a outra o alimenta mal; elas se odeiam e por isso devem viver em espaços distintos, uma longe da outra. Lévi-Strauss demonstrou que a duplicação de personagens semelhantes, mas nunca equivalentes, faz surgir o cromatismo como modo de operar mediações por meio da pequena diferença (Gonçalves 2001, 2010).

A posição em que se encontra um homem guna, entre a casa natal e a casa de casamento, sugere continuidades inequivalentes nas relações que ele mantém com o gênero feminino ao longo do ciclo de vida. A situação de "esperar por comida" estabelece uma correspondência diacrônica entre duas classes de mulheres ou dois contextos de residência, relação de repetição e diferença sintetizada por uma ética alimentar. Em outras palavras, um homem adulto, vivendo com seus afins, transfere sua expectativa de alimentação para outro espaço de provimento.

O ideal de substituição das relações consanguíneas aparece frequentemente nos conselhos matrimoniais, quando o sagla de uma comunidade diz ao jovem recém-casado que ele deve respeitar sua sogra e seu sogro como se fossem sua mãe e seu pai (Reverte Coma 1967:15-6). Um homem casado não passa, contudo, a chamar seus sogros por nan (mãe) e bab (pai). Ele 
ainda depende da realização vertical do parentesco como forma de se fixar à casa de casamento: seus filhos chamarão a mãe de sua esposa por muu (avó, mar) e o pai de sua esposa por dada (avô, sol). Finalmente, o homem casado que agora tem filhos, vivendo com seus afins consanguinizados, passa também a chamar seus sogros por muu e dada, em sentido terminológico mais largo, que indica respeito e reconhecimento.

\section{O amor perigoso: imagética da sedução}

Em algumas regiões da comarca de Gunayala, os Guna elaboram uma dimensão de fatalidade subjacente à relação com a diferença a partir de um relato etno-histórico que explica como seus avós chegaram ao mar. Provenientes da floresta tropical, eles se deslocaram em direção oeste através dos rios de vertente atlântica. Migraram em decorrência de uma mulher estrangeira causadora de mortes misteriosas (Martínez 2007): os homens que se apaixonavam por ela, após o casamento, conheciam uma morte sem motivo aparente. A moça foi afogada no rio e, depois de algum tempo, uma epidemia se espalhou pelas aldeias. Ninguém conseguia sair para trabalhar. O fato é que aquela mulher, filha de espanhóis, "no podía casarse con cualquiera, tenía que encontrar alguien que fuera como ella" (Martínez 2007:58). O relato sobre a mulher estrangeira pode ser lido como uma variante guna para a questão ameríndia relativa ao lugar problemático da diferença (Overing Kaplan 1975, 1981, 1984), introduz o problema da afinidade "necessária e perigosa", "condição e limite do socius" (Viveiros de Castro 2002:103).

O perigo da sedução é um dado recorrente nas representações guna sobre a atividade sexual. Aparece na experiência da loucura através de um sonho de copulação, ocasião em que o jaguar celeste descarta a imagem de um predador "para assumir a aparência igualmente perigosa de um parceiro sexual intensamente desejável" (Severi 2000:129-0). Uma mulher que deseja incitar o amor de um homem procederá por meio de uma estética da sedução, queimando a lagarta que ainda não se tornou mariposa e misturando as cinzas à tinta vermelha com que pintará o nariz (Nordenskiöld 1938:32).

Os jovens solteiros me diziam que o amor causa medo (tobe), não se pode escapar, "como uma tempestade" (burwa). Quando um rapaz não quer ter sexo com uma moça, seus amigos lhe perguntam assim: "por quê? você tem medo?" (be tobe?). Em Gunayala, ninguém mantém relações sexuais impunemente. O contato sexual é concebido como uma ligação muito forte, uma tempestade (burwa) que "deixa as pessoas misturadas" (oburwsa; em espanhol, mescladas). 
Diferentes povos ameríndios sustentam uma relação entre sedução e perigo a partir de uma dimensão estética ligada à agência feminina. ${ }^{15}$ Os Guna explicam a origem do desenho por meio da jornada de Giggadiriay, uma mulher que viajou para a aldeia de Galu Duipis, no mundo subterrâneo, onde viviam mulheres com enorme habilidade para manejar tesouras. Galu Duipis era um lugar perigoso para os homens: se algum deles se aproximasse, seria imediatamente capturado como marido. Giggadiriay foi a primeira a ver esse lugar, cheio de figuras em transformação. Depois, veio Olonagegiriay, uma mulher que aperfeiçoou a arte de desenhar em camadas (molagana) ${ }^{16}$ Ela dizia que as árvores estão cheias de escrituras e desenhos, todas pintadas de diversas e lindas cores. O fato de que a arte feminina do desenho teve origem nas superfícies vegetais me estimulou a refletir sobre a arquitetura das casas e seu simbolismo relativo à madeira a partir da lógica da sedução.

A edificação é uma atividade constante em Gunayala. Os homens adultos estão sempre ocupados com a substituição dos troncos que sustentam o telhado, com a reforma da cobertura vegetal ou com os pequenos consertos na estrutura de cana branca. A casa de residência é lugar de permanência e variação de recursos masculinos, na medida em que essa dinâmica de construção reiterada permite incorporar e fixar novos homens à família extensa. Em poucas palavras, as casas são formas aparentes de um contexto específico no "tempo intergeracional" (Margiotti 2010:58).

Repetindo os ensinamentos do profeta Ibeorgun, os Guna explicam que os homens casados estão representados pelos troncos principais que dão sustentação ao telhado. Ibeorgun ensinou que, em uma casa, os troncos de árvore necessitam um do outro e se apoiam mutuamente. ${ }^{17} \mathrm{Com}$ base nessa exegese dominante, os etnógrafos ofereceram frequentemente uma interpretação de ordem semiótica, ressaltando a centralidade da conexão entre o sogro e seu genro para a dinâmica de corresidência (Holloman 1969, 1976; Howe 1985). Margiotti (2010:56, tradução minha) observou que "a estrutura arquitetônica das casas guna codifica essa relação fundamental".

De modo complementar aos estudos precedentes, procurei alhures (Madi Dias 2015) desenvolver uma análise pragmática da arquitetura guna segundo a qual "os fenômenos simbólicos não são signos. Eles não estão vinculados à sua interpretação em uma estrutura de código" (Sperber 1974:97, tradução minha). ${ }^{18}$ Esta abordagem deve muito ao pragmatismo da velha senhora Permina, que interrompeu a explicação de seu filho Asinto, especialista em edificação na aldeia de Mammidub, fazendo todos rirem. Ela veio caminhando em nossa direção e, ainda de longe, gritou assim: "os homens aguentam o maior peso, eles devem trabalhar mais que as mulheres!". 
O comentário de Permina relaciona um homem sênior com a arquitetura a partir do fato incontestável de que a viga principal suporta o maior peso. Esta observação expressa uma informação quanto à necessidade de um homem se vincular à residência por meio da cooperação na forma do seu trabalho "para a casa". Com base nesta perspectiva, procurei pensar a casa guna como uma armadilha (Madi Dias 2015), no sentido de A. Gell (2001:184): dispositivo relacional que "comunica a noção de nexo de intencionalidades mediante formas e mecanismos materiais".

Um homem que pensa em sua esposa deve sair de casa bem cedo: waggudar, quando já se pode enxergar, mas ainda não se sente o calor do sol. Ele vai pescar bem longe, em alto mar, onde conseguirá peixes grandes. Um homem preguiçoso (wiegala), que não sai de casa para trabalhar, é considerado egoísta (binsaed suli, "não pensa nos outros") ou "malvado" (sunnasuli, "não é parente de verdade"). Ele corre o risco de ter seus pertences retirados da casa de casamento e levados para sua casa natal. Se quiser voltar a viver com sua esposa, deverá bater a cabeça no tronco central que dá sustentação ao telhado (buwar), reafirmando o compromisso de trabalhar para aquela unidade de residência.

Os Guna me diziam assim: negarbae (trabalhar para a casa). A casa assume no cotidiano a posição de um sujeito de direitos. Seu simbolismo masculino relativo à madeira, através das noções de sustento e estabilidade, perenidade e transcendência, reafirma a posição de um homem casado na dinâmica residencial em função da captura e incorporação do potencial produtivo dos seus afetos.

É durante a puberdade que um rapaz aprende a "pensar nos outros" e sua casa natal é a primeira unidade de residência para a qual ele trabalha. Vejamos então como essas questões se colocam em relação ao ciclo de vida dos homens.

\section{O reconhecimento da autonomia}

Acompanhei em Mammidub os esforços de um menino que começava a falar a partir dos estímulos de sua tia. Ela ensinava assim: be bab soged: ua an gumbie! (diga ao seu pai: quero comer peixe!). O pedido de comida está na base da consciência de parentesco: quando aprendem "para quem pedir comida", as crianças assumem uma posição ativa na economia corresidente. Diz-se que elas passam a demonstrar (oyoged) "como pensam por dentro". ${ }^{19} \mathrm{O}$ desenvolvimento da capacidade de expressão oral, resultando no pedido explícito de comida ou bebida (an gumbie! an gobbie!), conduz ao reconhecimento da autonomia como uma faculdade pessoal que justifica as volições infantis, as escolhas e o gosto individual. 
Até o início da puberdade, uma criança será chamada goe, isto é, "bebê". Já por volta dos 10 anos de idade, um menino passa a ser chamado massigwa ou simplesmente massi. De agora em diante, ninguém cantará para ele dormir.

\section{O desprivilégio massigwa}

Um rapaz massigwa está sempre reclamando: "esqueceram meu nome" (an nugiesa). Frequentemente, ao chegar em casa, ele percebe que não lhe guardaram comida. Se a tubulação se rompeu, receberá água de poço para o seu banho; suas roupas serão lavadas depois. Se a sua família recebe uma visita, ele perderá o seu lugar na rede.

O desprivilégio massigwa envolve um redimensionamento no sistema de atitudes em relação ao menino que deixa de ser chamado goe: uma forma de comunicação da matricasa, que passa a condicionar os recursos reprodutivos de que dispõe à sua contraparte produtiva. Se um rapaz sai para pescar, não lhe faltará comida. Se ele busca água no rio, terá água fresca para tomar banho. Se conserta o telhado, terá uma boa rede para dormir.

Em fase massigwa, um rapaz será iniciado no trabalho solitário, muitas vezes com a administração do remédio manisuar. ${ }^{20} \mathrm{~A}$ puberdade masculina corresponde a um período de pedagogia residencial, em que a família consanguínea está preparando o jovem rapaz. Ao longo dos anos em condição massigwa, ele aprende a "viver junto", "sentir-se junto" ou "compartilhar" (bulagwa iddoged), desenvolvendo suas capacidades de cooperação.

Margiotti (2010) percebeu a importância da distribuição de comida para a produção do parentesco em Gunayala. Seguindo seu insight importante, procurei ampliar o escopo das práticas de comunhão e gestão dos recursos da matricasa, considerando, além da alimentação, também o acesso às condições de beleza, descanso e alegria. Sem as circunstâncias ideais de alimentação, beleza e descanso, o jovem massigwa deixa também de rir. É nessa etapa do ciclo de vida que um menino alegre se torna um rapaz inexpressivo. Uma mulher em Mammidub me disse assim: "o coração dos homens está cheio de pensamentos, mas seus olhos não dizem nada".

Observei duas transformações importantes que acontecem na passagem da infância para a vida adulta: primeiro, um rapaz deixa de pedir comida; depois, ele terá seu almoço servido majestosamente na casa de casamento. 


\section{O almoço de um homem}

Na aldeia de Mammidub, a experiência vivida assume diariamente o sentido de produção de beleza ordinária. O cotidiano é imensamente investido de vontade e esmero: um fim em si mesmo. Uma situação especial de elaboração quase cênica é o momento de preparação dos pratos e de todo o ambiente em que comerá um homem. Ao servir o almoço, as mulheres manifestam seu pensamento em relação àqueles que têm fome. $\mathrm{O}$ almoço de um homem é um momento de demonstração de afeto, uma cena prosaica e ao mesmo tempo um grande acontecimento diário em que se produz uma experiência desejada e desejável.

As mulheres em Gunayala são pessoas extremamente altivas, orgulhosas e até arrogantes quanto aos produtos da sua cozinha, fontes incontestáveis de prestígio, reconhecimento e autoridade feminina em uma família guna. Pode acontecer de uma mulher perguntar para o seu esposo ou cunhado como ele deseja que se prepare a comida, mas esse comportamento não se dá com frequência ou regularidade. Normalmente, as mulheres decidem como, quanto e quando cozinhar ou preparar as bebidas. Também decidem sobre a quantidade de comida ofertada à casa natal de um homem casado e vivendo com seus afins. Um homem não sabe muito bem a que horas a comida ficará pronta ou como será preparada, de modo que a refeição principal produz um contexto de expectativa e até ansiedade.

Chegando do trabalho, os homens costumam descansar dentro da sua canoa enquanto esperam que a comida fique pronta. Uma criança pode eventualmente avisar. Quando a comida está pronta, a mulher mais velha se encarrega de reservar os pratos de comida. Ela menciona o nome próprio de cada pessoa, exercendo sua prerrogativa de justiça na divisão dos peixes. Os Guna me diziam sempre que la abuela pensa em quem precisa se alimentar. As mulheres podem organizar pequenos turnos, definindo a sequência em que os homens comerão. O homem em posição de sogro (sagga) come antes dos demais. Entre aqueles de uma mesma geração, o sentido de prioridade é dado em função dos aportes de provimento, podendo causar controvérsias e conflitos corresidentes.

A esposa é quem prepara o espaço da refeição, normalmente no quintal da família. Ela providencia um banco para seu marido se sentar e outro banco na mesma altura para que ele possa apoiar seu prato, procurando um lugar na sombra quando o sol está forte. Durante o tempo em que um homem está comendo, sua esposa oferece sal, limão e pimentas em um prato pequeno. Ela avalia o consumo da sopa em relação à porção de carne e pode oferecer mais caldo (nisa). As mulheres estão sempre atentas em repor o prato de 
condimentos, inclusive limpando esse prato, que às vezes apresenta um líquido resultante do caldo de limão misturado com sal.

É comum que um homem termine a refeição elogiando a comida ou o empenho de sua mulher em servi-lo. Alguns brincam dizendo que suas mulheres são buenas saloneras (boas garçonetes), em tom elogioso e com um sorriso largo. Elogios mais explícitos podem aparecer nas seguintes formas: yeer gulege ou yeer malege (está gostoso); an ome angi nued dae! (minha mulher é boa para mim). Quando um homem termina de comer, sua esposa traz água para que ele possa lavar as mãos e enxaguar a boca.

Com o casamento, o envelhecimento aparece pela primeira vez no horizonte existencial de um rapaz. Um homem casado é, enfim, chamado massered (homem), palavra cuja formação deriva de masi + seredi (banana velha). ${ }^{21} \mathrm{~A}$ palavra ome (mulher) deriva das formas verbais omergued, omeloed, sinônimos que podem ser traduzidos por "distribuir" ou "multiplicar".22 A gestão e a distribuição de recursos, sujeitas ao exercício da justiça como prerrogativa feminina, assumem o sentido de uma comunicação analógica (não verbal):

1. veiculando uma informação sobre as condições de permanência na casa (em fase massigwa);

2. ostentando o esforço de consanguinização da afinidade (na ocasião do almoço de um homem casado).

\section{A uxorilocalidade (quase) enunciada}

Trabalhei até aqui com dados que se encontram dispersos pela etnografia guna, cuja organização em conjunto tem a vantagem de oferecer uma perspectiva integral sobre o ethos de residência e suas consequências para a experiência masculina. Valorizando a relação de afinidade feminina, apresentei elementos que permitem compreender a aliança nos termos de um drama residencial que ressoa no mito, no rito, no cotidiano e no ciclo de vida dos homens.

Quero finalizar com uma reflexão proveniente de um trabalho em curso sobre as canções de ninar como contexto privilegiado de comunicação oral, situação "quase ritual" (Severi 2014:165) de enunciação do drama da residência entre os Guna. Considerando o escopo deste artigo, não há espaço aqui para trabalhar com exemplos do corpus textual em língua guna. Nesta seção final, meu objetivo é apontar linhas futuras de investigação que serão desenvolvidas oportunamente. 
O mito conta que as canções de ninar foram ensinadas por uma das irmãs Nadili, capturada na rede enquanto descansava. No cotidiano, essas canções exprimem uma infinidade de temas e situações singulares: seu conteúdo é improvisado de acordo com a relação entre a cantora e o bebê para quem se oferece acalanto. A cantora pode estar em posição de nan (mãe), muu (avó), anmor (tia), ior (irmã/prima mais velha, Ego feminino) ou buna (irmã/prima, Ego masculino). Encontramos nos versos situações tais como o parto difícil, o bebê que é xamã, o menino malvado, a briga entre cunhados, a doença ou a morte na família, a falta d'água, a escassez de comida...

É comum que o conteúdo dos versos assimile dados biográficos ou eventos recentes, como nas canções que eu recolhi para o menino que não tem pai, para o irmão mais velho, para a menina que acabou de chegar da cidade etc. De maneira geral, os versos improvisados se referem ao passado e ao contexto presente para então sugerir uma sequência no futuro. Ressaltam assim uma dimensão de "caminho pessoal", como me explicou a velha Permina: "vamos cantando por onde o bebê andou, mas não sabemos quais caminhos ele ainda vai percorrer".

Expressando incerteza, as mulheres cantam o futuro virtuoso de um pescador ou de uma coletora de água. A cantora "inventa"23 o futuro do bebê, comunicando expectativas quanto ao desenvolvimento das "capacidades afetivas" ou "afecções de gênero". O ideal de cooperação indica a maneira "adequada" (nabiri) para o desenvolvimento infantil: aprende-se a pensar nos outros e a demonstrar seu pensamento por meio das habilidades do corpo (por exemplo, pescar ou coletar água).

\section{A linguagem da intimidade}

Minha reflexão sobre as canções de ninar como modalidade de enunciação doméstica se beneficia de uma perspectiva interacional ou sistêmica. Os trabalhos de Gregory Bateson surgem portanto como referência incontornável:

sua classificação dos tipos de relações - complementares e simétricas - e seu interesse pela "lógica cultural" dos pares, oposição e divergência, fizeram dos modos de relação um problema teórico (Strathern 1998:71, tradução minha).

Deslocando o olhar dos termos para as relações (cf. Bateson 1936, 1982; Strathern 1998), eu pude organizar a riqueza e a diversidade de temas tratados nas canções de ninar em torno de duas possibilidades de interação: a filiação cruzada (cross-sex, mãe-filho) e a filiação paralela (same-sex, mãe-filha). ${ }^{24} \mathrm{O}$ conteúdo dos cantos revela uma perspectiva localizada de percepção das relações mútuas, em que tanto a cantora quanto o bebê aparecem como sujeitos da interação corresidente. 
Tudo se passa como se, em uma notação de parentesco, passássemos a considerar a própria relação de filiação como um termo, de modo que as canções ofereçam uma perspectiva triádica (mãe+bebê x outros). ${ }^{25}$ Uma ocorrência sintática própria às canções de ninar permite esclarecer meu argumento:

$\begin{array}{lllll}\text { be } & \text { ani } & \text { gilumala } & \text { mimmigana } & \text { abindaggoe } \\ \text { você } & \text { mim } & \text { seus tios } & \text { filhos } & \text { receber (fut.) }\end{array}$

[quando você for grande]

você (-mim) vai receber seus primos (os filhos do seu tio)

Vejamos outros exemplos:

be ani sabbini guedaniggi bunamala abalagi

você (-mim) vem crescendo em meio às suas irmãs

be ani gwenaddiganaba dodoedi gudoe

você (-mim) estará brincando com seus familiares [no futuro]

be ani emisgindi bibbigwa

agora você (-mim) ainda é pequeno

be ani emisgindi boedigi binsaemai

agora você (-mim) só pensa em chorar

A forma composta be ani (você-mim) aparece sistematicamente nas canções de ninar. Refere-se à segunda pessoa do singular (be) de modo combinado à primeira pessoa do discurso (ani). Trata-se de um recurso poético que exprime carinho e intimidade, com sentido próximo de "meu você". Esse dado me estimulou a refletir sobre as canções de ninar a partir do problema psicanalítico do objeto primário.

Segundo a teoria psicanalítica ortodoxa, o recém-nascido é geralmente narcisista: sua satisfação é percebida em relação ao próprio Ego ou à psyché indiferenciada (mãe+bebê). O narcisismo primário (Freud 1914) corresponderia a uma primeira etapa da economia libidinosa, em que a fonte de satisfação é irrelevante para o bebê - seja a satisfação autoinduzida, como na forma de arrotos ou eliminação das fezes, seja exterior, como no caso da relação com o corpo da mãe. O impulso em direção ao seio materno expressa, para Freud, um instinto de preservação que não se confunde com a libido, isto é, que não pressupõe o reconhecimento de uma fonte particular de gratificação. De acordo com esta perspectiva, o estabelecimento de "objetos catexiais" ${ }^{26}$ desvinculados de Ego aconteceria em contexto paralelo à alimentação, a partir do complexo de Édipo, que estabelece dois modelos originais para o exercício do desejo: para os meninos, a mãe; para as meninas, o pai. 
A visão protofeminista de Alice Balint (1939) permite uma aproximação diferente em torno da figura da mãe como objeto do primeiro amor. As ideias contidas em seu artigo "Love for the Mother and Mother Love" foram decisivas para a formulação do conceito de amor primário (M. Balint 1965). Rejeitando a teoria do narcisismo primário, M. Balint procurou compreender a especificidade do vínculo original com a mãe nos termos de uma mistura harmoniosa interpenetrante (harmonious interpenetrating mix-up), como no exemplo clássico de um peixe que está dentro d'água. Assim como o mar está para um peixe, a mãe surge para o bebê como objeto indestrutível e inteiramente disponível.

Na esteira da discussão psicanalítica sobre o vínculo primário, Nancy Chodorow (1978) sugeriu a possibilidade de pensar a masculinidade como relativa ao verdadeiro sexo frágil. Oferecendo uma crítica feminista à psicanálise, a autora argumenta que a vulnerabilidade masculina se refere ao desejo pelo "sexo oposto" como situação de retorno ao trauma da perda e da separação do primeiro amor. No nível das representações inconscientes, a experiência afetiva (heterossexual) colocaria, para os homens, o problema da atualização do vínculo original.

As canções de ninar permitem abordar o problema do vínculo primário sem aderir à teoria psicanalítica do desejo, produzida com base na tragédia grega, mas levando em conta o drama guna da residência: permanecer na casa ou partir para viver em outro lugar. A casa é lugar por excelência de segurança emocional e afirmação das relações de parentesco. Em muitas canções, as mulheres produzem uma aglutinação morfológica para se referirem à casa de residência (nega) como um ninho $(u)$ em cuja cavidade (ya) o bebê está posicionado (gi) - negauyagi ("casa-ninho").

\section{A linguagem da perda e da separação}

As canções de ninar tematizam frequentemente a perenidade ou a dissolução dos vínculos afetivos: as meninas permanecerão na casa até que se tornem velhas ("nesta casa-ninho", negauyagi). Os meninos vão esquecer a cantora e deixar de pensar nela (binsaed suli); talvez eles passem a viver na cidade do Panamá, "morada dos demônios" (niagana nega) ou "comunidade dos demônios" (nia dolagana bali).

Durante o meu trabalho de campo, conforme eu podia entender melhor o conteúdo dos versos, as canções para os meninos passaram a chamar minha atenção para o modo como mobilizam estímulos contraditórios (double bind), traduzidos pelos idiomas da memória e da residência: pensar em alguém ou esquecer, permanecer na casa ou partir. Percebi finalmente uma estrutura recorrente de representações em torno de duas metáforas emocionais: casa-ninho, casa dos demônios. 
Os discursos sobre as emoções que encontramos nessas canções manipulam imagens sobre o tempo a partir de dois espaços de referência:

- tempo presente, AQUI: casa-ninho (negauyagi), espaço de segurança emocional;

- tempo futuro, LÁ: casa do diabo (niagana nega), espaço de dúvida e ansiedade.

As canções para os meninos oferecem uma imagem do futuro que exprime a ambiguidade e a ansiedade causadas pelo novo, pelo desconhecido, pelo incompreensível. Conforme notou Severi (1987), essas dimensões aparecem no pensamento tradicional guna em relação à representação do sofrimento e da dor.

Trabalhando com uma amostra de 24 canções de ninar, observei que nenhuma delas menciona o casamento; evocam uma espécie de mundo ideal, inteiramente baseado na consanguinidade. Muitos versos dizem que aquele menino vai se esquecer da cantora, mas nenhuma canção menciona o fato de que, quando for grande, ele vai se casar e morar com outra família, trabalhando para outra unidade de residência. A afinidade não dita, "mal necessário" relativo ao caráter imperativo da aliança, assume nas canções de ninar o sentido de um segredo público (Taussig 1999): aquilo que todos sabem que não devem saber.

O segredo referente à aliança permite afinal compreender o parentesco guna nos termos de um drama residencial. Sair de casa: sair para pescar, sair para casar.

Recebido em 25 de outubro de 2016

Aprovado em 11 de maio de 2017

Diego Madi Dias

Laboratoire d'anthropologie sociale du Collège de France, Paris, França. 


\section{Notas}

* Realizei 20 meses de trabalho de campo no Panamá, principalmente nas aldeias de Mammidub e Uggubseni (comarca de Gunayala), graças aos recursos de Smithsonian Institution. Nesse contexto, agradeço pelo apoio fundamental de Fernando Santos-Granero. O financiamento da Fondation Fyssen me permitiu organizar o material relativo às canções de ninar no âmbito de minha pesquisa pós-doutoral no Laboratoire d'anthropologie Sociale (LAS) du Collège de France. Agradeço pela atenção e interesse de Carlo Severi, Cyril Menta e demais colegas do LAS. Apresentei uma versão preliminar deste artigo no Séminaire d'anthropologie americaniste (SAA) e agradeço às organizadoras Bonnie Chaumeil, Isabelle Daillant e Anath Ariel de Vidas pela oportunidade de discutir meu trabalho. Agradeço sobretudo ao orientador de minha tese de doutorado no PPGSA/UFRJ, Marco Antonio Gonçalves, cuja supervisão foi decisiva para os caminhos de análise desenvolvidos neste artigo. Finalmente, agradeço aos pareceristas anônimos de Mana, cujos comentários generosos me ajudaram a tornar o texto mais claro.

1 A literatura antropológica utilizava até recentemente as grafias "Kuna" ou "Cuna" para se referir a essa população ameríndia. Procuro aqui seguir as convenções definidas pelos Congresos Generales Gunas e formalizadas pelo projeto EBI - Educación Bilingüe Intercultural (Nan Garburba Oduloged Igar). Originários da floresta colombiana, os Guna migraram ao longo do século XIX em direção à porção oriental da costa atlântica do Panamá. Na região que hoje corresponde ao arquipélago de San Blás, a comarca indígena de Gunayala foi criada em 1938. A população atual é de 80.526 habitantes (censo nacional 2010).

2 A ênfase na socialidade pública, adulta e masculina tem uma longa tradição na etnologia. Para além de toda a sua contribuição evidente e inquestionável, penso que essa abordagem produziu eventualmente uma concepção desgendrada de humanidade. Faz 80 anos que Lévi-Strauss (1936:283, tradução e ênfase minhas) escreveu assim sobre os Bororo: "A aldeia inteira partiu no dia seguinte em trinta canoas, deixando-nos sozinhos com as mulheres e as crianças nas casas abandonadas". Mais recentemente, E. Viveiros de Castro (1993:202, nota 20) se referiu à "dominância simbólica masculina" como relativa à predação ontológica englobante. Anne-Christine Taylor (2000), por sua vez, afirmou que a afinidade masculina corresponde ao modelo de relação propriamente social entre os Jívaro. Em um esforço de comparação com a região da Melanésia, Philippe Descola (2001:91, tradução minha) sustentou que "gênero não é uma categoria saliente nas sociedades sul-americanas".

3 Em resposta às minhas perguntas sobre a dinâmica de residência pós-marital, Pablo Nuñes Perez me contou a história das filhas das estrelas durante a minha primeira incursão ao campo entre os Guna (julho 2011). Naquela ocasião, ele me disse que essa história "explica tudo". Posteriormente, cotejei a versão de Pablo com aquelas disponíveis na literatura etnográfica, completando algumas lacunas.

4 Bebida medicinal preparada a partir da infusão de madeiras avermelhadas. 
5 Bebida preparada com banana cozida e cacau.

6 Diferentes pessoas em Mammidub me ajudaram a elaborar uma descrição do matrimônio entre os Guna. Durante o meu trabalho de campo, tive a oportunidade de presenciar duas festas gagalegged nessa mesma aldeia (julho 2011, maio 2014). A descrição que segue está baseada na cerimônia a que assisti em 2014.

7 De acordo com Prestán (1975:92), após consultar a família do noivo, o casamento era realizado na próxima festa de inna (chicha fuerte, cerveja de milho fermentada com caldo de cana-de-açúcar). Reverte Coma (1967:12-13) menciona que o matrimônio acontecia quando havia quantidade suficiente de bebida fermentada. Holloman (1969:161) e Howe (1985:318) contam que o noivo podia ser surpreendido enquanto bebia inna em uma cerimônia de puberdade ou nominação.

8 Como entre os Piaroa, "você pisca os olhos e perde um casamento" (Overing 2002:1, tradução minha).

9 Parte do conselho matrimonial a que assisti em Mamitupu (maio 2014), traduzido simultaneamente para o espanhol por Pablo Nuñes Perez e registrado em meu caderno de notas em português.

10 O conceito de produção é utilizado aqui conforme a sugestão de Joanna Overing (1991), isto é, em relação ao engajamento pessoal produtivo do socius, levado a cabo a partir de intenções morais e estéticas compartilhadas. No contexto da etnografia americanista, Cecilia McCallum $(1999,2001)$ desenvolveu para os Kaxinawa a noção de gênero como capacidade. A relação entre ação, pensamento e afeto foi formulada originalmente por Peter Gow (1991) para os Piro. Com base no material amazônico, Luisa Belaunde (2005) apresentou uma síntese comparativa sobre o coração que pensa (cf. Lagrou 2008:17-21). Também para os Guna se pode afirmar que "ação, pensamento e afeto são mutuamente constitutivos" (Overing 1999:92).

11 No contexto da etnologia americanista, Viveiros de Castro (1996b:128) trabalhou com a noção de afecção no sentido das "capacidades que singularizam cada espécie de corpo".

12 Cf. N-C Mathieu (2007): Une maison sans fille est une maison morte. La personne et le genre en sociétés matrilinéaires et/ou uxorilocales. [Uma casa sem menina é uma casa morta].

13 Sobre abundância e escassez, ver Margiotti (2010:71-80). Oros sopa: sopa de coco com arroz, em que uma pequena quantidade de proteína animal é misturada ao conjunto. Dulemasi: sopa de coco com bananas ou inhame, acompanhada por uma porção individual de peixe, caranguejo ou carne de caça.

14 Cf. notou Margiotti (2010:55. Na mesma direção, Vanessa Lea argumentou que os laços com a residência natal são indissolúveis para os homens Mebêngôkre-Kayapó. Entre os Kayapó, parte da caça e da pesca dos homens casados deve ser endereçada à casa da mãe (Lea 1993:269). 
15 A partir do exemplo Wayana, Lucia Van Velthem (2003) sintetizou essa relação em uma formulação poderosa: o belo é a fera (2003). Ver também: Lagrou (2007) para os Kaxinawá; Belaunde (2013) para os Shipibo-Conibo; Beysen (2013) para os Ashaninka.

16 Os Guna são conhecidos internacionalmente por suas molas, desenhos abstratos ou figurativos formados pela superposição de camadas de tecido em reverse appliqué. A confecção dessa arte têxtil é um trabalho feminino e as molas são utilizadas como parte da vestimenta tradicional da mulher guna. Retiradas do complexo indumentário, as molas são isoladas como objetos de arte e podem ser encontradas em diversos museus ao redor do mundo. São também vendidas em contexto de turismo étnico. As primeiras lojas de "artesanato indígena" surgiram nos anos 1950, na Cidade do Panamá, quando os estrangeiros descobriram as molas e passaram a colecioná-las. A partir dos anos 1980, a venda das molas se tornou uma importante fonte de renda em Gunayala. Ver Perrin (1999).

17 A arquitetura guna oferece uma imagem de mutualidade e interdependência de gêneros que eu não poderei abordar aqui por falta de espaço. Cabe notar, contudo, que esta perspectiva de interdependência se apresenta de maneiras diversas. No contexto do casamento, por exemplo, mesmo se é a mãe quem dá a palavra final, parece importante destacar que é o pai da noiva quem vai buscar o rapaz recém-casado nos dias subsequentes. Se a casa, como sujeito de direitos, remete ao núcleo de mulheres consanguíneas, sua materialidade coloca em evidência um simbolismo predominantemente masculino. Ver Madi Dias (2015:60-69) para uma discussão mais desenvolvida sobre a casa guna como armadilha, incluindo uma descrição detalhada de sua arquitetura e um diálogo com a literatura: Lévi-Strauss (1979, 1984); Carsten e Hugh-Jones (1995); Lea (2012).

18 Sperber (1974:131, tradução minha) definiu o saber simbólico como um dispositivo cognitivo que implica dois aspectos: "por um lado, um deslocamento da atenção, ou focalização; por outro lado, uma busca na memória, ou evocação". Procuro sublinhar estes dois aspectos da experiência masculina, isto é, a necessidade de "esquecer" as mulheres consanguíneas (cf. Margiotti 2010) e "pensar" na esposa (an be binsaoe).

19 Na mesma direção, os Kayapó-Xikrin valorizam o papel das crianças em "mostrar", mais que aprender (Cohn 2000:94): "os Xikrin dão como motivo da participação da criança desde cedo nos rituais, em primeiro lugar, a importância de que ela mostre (e não que aprenda) seu lugar em dado ritual, de que seu kukradjà [conhecimento] 'apareça', seja 'mostrado' (amerin)".

20 Infusão de madeiras avermelhadas. Paolo Fortis (2008:79) registrou seu efeito afrodisíaco.

21 an gassi seredi, e.g., quer dizer "minha rede está velha" (precisa ser consertada ou trocada).

22 Por exemplo, a sentença anga masi omeloed é entendida por "sirva-me mais comida", com ênfase para o sentido de abundância (diferente da forma napi, que significa "outra vez" e é utilizada para repetir). 
23 inventar: nonogi binsaed (pensar dentro da cabeça).

24 Ver Belaunde (2005): cruzados e paralelos.

25 Vanessa Lea (2004) analisou o fenômeno linguístico que designou de "termos triádicos de referência", procedimento retórico que permite realçar uma rede de relações. Entre os Mebêngôkre-Kayapó do Brasil Central, os termos triádicos incluem três elementos em uma relação de parentesco e/ou amizade formal, isto é, abrangem uma terceira posição, além do locutor e do interlocutor.

26 Freud definiu a catexia como um processo de fixação de energia psíquica em uma representação mental.

\section{Referências bibliográficas}

BALINT, A. 1939. "Love for the mother and mother love" (1939). Published posthumously in the International Journal of Psycho-Analysis (XXX, 1949) and collected in: M. Balint. 1965. Primary love and psycho-analytic technique. London: Tavistock Publications.

BALINT, M. 1965. Primary love and psycho-analytic technique. London: Tavistock Publications.

BATESON, G. Naven. 2008 [1936]. São Paulo: EdUSP.

2000 [1972]. Steps to an ecology of mind. Chicago: The University of Chicago Press.

. 1982. "De la clasificación al proceso". In: Espíritu y Naturaleza. Buenos Aires: Amorrortu, pp. 211-219.

BELAUNDE, L. E. 2005. El recuerdo de Luna. Género, sangre y memoria entre los pueblos amazónicos. Lima: CAAAP.

. 2013. "Movimento e profundidade no kene shipibo-conibo da Amazônia Peruana". In: E. Lagrou \& C. Severi (orgs.), Quimeras em diálogo: grafismo e figuração nas artes indígenas. Rio de Janeiro: 7Letras, pp 199-222. BERGSON, H. 1990 [1896]. Matéria e
Memória. Ensaio sobre a relação do corpo com o espírito. São Paulo: M. Fontes.

BEYSEN, P. 2013. "A arte gráfica dos traços fortes entre os Ashaninka do Oeste Amazônico". In: E. Lagrou \& C. Severi (orgs.), Quimeras em diálogo: grafismo e figuração nas artes indígenas. Rio de Janeiro: 7Letras, pp 223-245.

BOLTANSKI, L. 1990. L'amour et la justice comme compétences. Trois essais de sociologie de l'action. Paris: Métailié.

CHAPIN, M. 1989. Pab igala: historias de la tradición kuna. Quito: Ediciones Abya Yala.

CHODOROW, N. 1978. The reproduction of mothering. Berkeley: University of California Press.

CLASTRES, P. 2003 [1974]. A sociedade contra o estado. Pesquisas de antropologia política. São Paulo: Cosac Naify.

COHN, C. 2000. A criança indígena: a concepção Xikrin da infância e do aprendizado. Dissertação de Mestrado, PPGAS-FFLCH/USP.

DELEUZE，G. \& GUATTARI，F. 1995 [1980]. Mil platôs. Capitalismo e esquizofrenia. São Paulo: Ed. 34. 
DESCOLA, P. 2001. "The genres of gender: local models and global paradig$\mathrm{ms}$ in the comparison of Amazonia and Melanesia". In: T. Gregor \& D. Tuzin (eds.), Gender in Amazonia and Melanesia: an exploration of the comparative method. Berkeley: University of California Press, pp 91-114.

FORTIS, P. 2008. Carving wood and creating shamans. An ethnographic account of visual capacity among the Kuna of Panama. Doctoral Dissertation, University of St. Andrews.

FREUD, S. 2010 [1914]. Introdução ao narcisismo. São Paulo: Companhia das Letras.

GELL, A. 2001. "A rede de Vogel, armadilhas como obras de arte e obras de arte como armadilhas". Arte e Ensaios - PPGAV/UFRJ, ano VIII, 8:174-191.

GONÇALVES, M.A. 2001. O mundo inacabado. Ação e criação em uma cosmologia amazônica. Etnografia pirahã. Rio de Janeiro: Editora UFRJ. . 2007. "Do cromático ao diatônico: as mitológicas e o pensamento ameríndio". Revista Brasileira de Ciências Sociais, 22(65):173-181.

. 2010. Traduzir o outro: etnografia e semelhança. Rio de Janeiro: 7Letras.

GOW, P. 1991. Of mixed blood. Kinship and history in Peruvian Amazonia. Oxford: Clarendon Press.

GUERRA, M.D. \& SÁNCHEZ, L. 2000. Los indios Kuna: mitología, mujer y territorio. Medellín: Instituto Misionero de Antropología / Ethnia (85).

HIRSCHFELD, L. \& HOWE, J. 1981. "The star girls' descent: a myth about men, women, matrilocality, and singing". Journal of American Folklore, 94(373):292-322.

HOLLOMAN, R. 1969. Developmental change in San Blas. Doctoral Dissertation, Northwestern University. . 1976. "Cuna household types and the domestic cycle". In: M. Helms
\& F. Loveland (eds.), Frontier adaptations in Lower Central America. Philadelphia: Institute for the Study of Human Issues, pp. 131-150.

HOWE, J. 1985. "Marriage and domestic organization among the San Blas Kuna". In: W. Darcy \& M. Correa (eds.), The botany and natural history of Panama. St. Louis: Missouri Botanical Garden, pp.317-331.

HOWE, J.; SHERZER, J. \& CHAPIN, M. 1980. Cantos y oraciones del congreso Cuna. Panamá: Editorial Universitaria.

LAGROU, E. 2006. "Rir do poder e o poder do riso nas narrativas e performances Kaxinawa". Revista de Antropologia, 49(1):55-90. 2007. A fluidez da forma: arte, alteridade e agência em uma sociedade amazônica (Kaxinawa, Acre). Rio de Janeiro: TopBooks.

2008. "El corazón que piensa". In: L. E. Belaunde (org.), El recuerdo de Luna. Lima: CAAAP, pp. 17-21.

LAGROU, E. \& SEVERI, C. (orgs.). 2013. Quimeras em diálogo: grafismo e figuração nas artes indígenas. Rio de Janeiro: 7Letras.

LEA, V. R. 1993. "Casas e casas Mebengokre (Jê)". In: E. Viveiros de Castro \& M. Carneiro da Cunha (eds.), Amazônia: etnologia e história indígena. São Paulo: NHII-USP/FAPESP, pp.265-284.

. 2004. "Aguçando o entendimento dos termos triádicos Mebêngôkre via os aborígenes australianos: dialogando com Merlan e outros". Liames, 4:29-42.

LÉVI-STRAUSS, C. 1936. "Contribution à l'étude de l'organisation sociale des Indiens Bororo". Journal de la Société des américanistes, 28(2):269-304. . 1976 [1969]. As estruturas elementares do parentesco. Petrópolis: Vozes. 
1979. "A organização social Kwakiutl". In: A via das máscaras. Lisboa: Martins Fontes, pp. 143-167. 1984. Paroles données. Paris: Plon. 2000. "Postface". L'Homme [en ligne], 154-155 | avril-septembre 2000, mis en ligne le 04 mai 2007. Disponível em: http://lhomme.revues.org/57; DOI: $10.4000 /$ homme.57. Acesso em 02/05/2017.

2006. A origem dos modos à mesa. Mitológicas 3. São Paulo: Cosac Naify.

LIPSET, D. 2009. "O que faz um homem? Relendo Naven e The Gender of the Gift". Cadernos Pagu, 33:57-81.

LOPEZ, G. \& JOLY, L. 1981. "Singing a lullaby in Kuna: a female verbal art". Journal of American Folklore, 94(373):351-358.

MADI DIAS, D. 2015. Gênero disperso: estética e modulação da masculinidade Guna (Panamá). Tese de Doutorado, PPGSA-IFCS/UFRJ.

MARGIOTTI, M. 2010. Kinship and the saturation of life among the Kuna of Panamá. Doctoral Dissertation, University of St. Andrews.

. 2011. "Bodies, relatedness and density: a view from the Kuna house". Paper presented at the School of Anthropology and Museum Ethnography, University of Oxford. Mimeo.

MARTÍNEZ, M.M. 2007. De Tule Nega a Kuna Yala. Mediación, territorio y ecología en Panamá 1903-2004. Tesis Doctoral, Universitat Autònoma de Barcelona/ École des Hautes Études en Sciences Sociales.

MATHIEU, N-C. (ed). 2007. Une maison sans fille est une maison morte. La personne et le genre en sociétés matrilinéaires et/ou uxorilocales. Paris: Maison des Sciences de L'Homme.

McCALLUM, C. 1999. "Aquisição de gênero e habilidades produtivas. O caso Kaxinawá". Revista Estudos Feministas, 7(1-2):157-175.
2001. How real people are made. Gender and sociality in Amazonia. Oxford: Berg Publishers.

McCOSKER, S. 1974. The lullabies of the San Blas Cuna of Panama. Göteborg: Etnografiska Museet.

NORDENSKIÖLD, E. 1938. An historical and ethnological survey of the Cuna indians. Göteborg: Etnografiska Museet.

ORTNER, S. 1974. "Is female to male as nature is to culture?". In: M. Rosaldo \& L. Lamphere (eds.), Women, culture, and society. Stanford: University of California Press, pp. 67-87.

OVERING, J. 1975. The Piaroa; a people of the Orinoco Basin: a study in kinship and marriage. Oxford: Clarendon Press.

. 1981. "Amazonian anthropology". Journal of Latin American Studies, 13(1):151-164.

1984. "Elementary structures of reciprocity: a comparative note on Guianas, Central Brazilian and NorthWest Amazon sociopolitical thought". In: A. Colson \& D. Heinen (eds.), Themes in political organization: the Caribs and their neighbours. Caracas: Fundación La Salle, pp. 331-348.

. 1986. "Men control women? The 'Catch 22' in gender analysis". International Journal of Moral and Social Studies, 1(2):135-156.

1991. "A estética da produção: o senso da comunidade entre os Cubeo e os Piaroa". Revista de Antropologia, 34(2):7-33.

. 1999. "Elogio do cotidiano: a confiança e a arte da vida social em uma comunidade amazônica". Mana , 5(1):81-107.

. 2000. "The efficacy of laughter. The ludic side of magic within Amazonian sociality". In: J. Overing \& A. Passes (eds.), The anthropology of 
love and anger. The aesthetics of conviviality in native Amazonia. London: Routledge, pp. 64-81.

. 2002. An Amazonian philosophy of folly. St. Andrews, EASA: 'Comedy, Mischief, Deceit'.

. 2012. "Adiwa! Piaroa philosophies of power, violence, ingestion, excretion, blood and beauty". Paper presented at the Institute of Cultural Analysis, Vienna. Mimeo.

PERRIN, M. 1999. Magnificent molas. The art of the Kuna indians. Paris: Flammarion.

PRESTÁN SIMÓN, A. 1975. El uso de la chicha y la sociedad Kuna. México/ DF: Instituto Indigenista Interamericano.

REVERTE COMA, J.M. 1967. El matrimonio entre los indios Cuna de Panamá. Panamá: Edilito.

SANTOS-GRANERO, F. 1991. The power of love: the moral use of knowledge amongst the Amuesha of Central Peru. London: Athlone Press.

SEVERI, C. 1987. "The invisible path. Ritual representation of suffering in Cuna traditional thought". Anthropology and Aesthetics, 14:66-85. Peabody Museum / Harvard University. . 2000. "Cosmologia, crise e paradoxo. Da imagem de homens e mulheres brancos na tradição xamânica kuna". Mana, 6(1):121-155.

. 2014. "Être patrocle: jeux et rituels funéraires dans l'Iliade". In: C. Severi \& C. Fausto (eds.), L'image rituelle. Paris: L'Herne, Cahiers d'anthropologie sociale, 10, pp. 147-173.

SHERZER, J. 1990. Verbal art in San Blas: Kuna culture through its discourse. Cambridge: Cambridge University Press.
SPERBER, D. \& WILSON, D. 1986. Relevance: communication and cognition. Cambridge: Blackwell.

SPERBER, D. 1974. Le symbolisme en général. Paris: Hermann.

SPINOZA, B. 1983 [1677]. Ética. São Paulo: Abril Cultural.

STRATHERN, M. 1988. The gender of the gift. Problems with women and problems with society in Melanesia. London: University of California Press.

. 2010. "Porcos e celulares: uma conversa com Marilyn Strathern sobre antropologia e arte". Revista PROA de Antropologia e Arte, 1(2) [on-line].

TAUSSIG, M. 1999. Defacement: public secrecy and the labor of the negative. Stanford: Stanford University Press.

TAYLOR, A-C. 2000. "Le sexe de la proie. Représentations jivaro du lien du parenté". L'Homme, 154-155:309-333.

VAN VELTHEM, L.H. 2003. O belo é a fera: a estética da produção e da predação entre os Wayana. Lisboa: Assírio \& Alvim / Museu Nacional de Etnologia.

VIVEIROS DE CASTRO, E. 1993. "Alguns aspectos da afinidade no dravidianato amazônico". In: E. Viveiros de Castro \& M. Carneiro da Cunha (orgs.), Amazônia: etnologia e história indígena. São Paulo: NHII/ USP-FAPESP, pp. 149-210.

. 1996a. "Images of nature and society in Amazonian ethnology". Annual Review of Anthropology, 25(1):179-200.

1996b. "Os pronomes cosmológicos e o perspectivismo ameríndio". Mana, 2(2):115-144.

. 2002. A inconstância da alma selvagem. São Paulo: Cosac Naify. 
A ALIANÇA ENQUANTO DRAMA: EST/ÉTICA DA MASCULINIDADE NO CONTEXTO DE UMA ECONOMIA AFETIVA UXORILOCAL (GUNA, PANAMÁ)

\section{Resumo}

O artigo lança um olhar para os Guna a partir da casa de residência, espaço privilegiado de comunhão e compartilhamento de recursos. Meu objetivo é demonstrar que a residência em Gunayala movimenta uma economia doméstica dos pensamentos: os Guna dizem que a pessoa preguiçosa (wiegala) não pensa nos outros (binsaed suli). Ela é considerada sunnasuli - "não é parente de verdade" ou, simplesmente, "malvada". O dom é a linguagem utilizada para dar conta das transações que ocorrem no registro da intimidade. Procuro explorar as consequências da ética da convivialidade guna no que se refere à masculinidade, na medida em que os homens são levados a pensar em sua esposa como condição de fixação e permanência na casa dos afins. O problema da troca é examinado a partir das raízes mitológicas, rituais e sociológicas da uxorilocalidade, permitindo compreender o esforço de consanguinização da afinidade nos termos de um drama residencial: o drama da aliança ou a aliança enquanto drama.

Palavras-chave: Gênero, Intimidade, Ética, Uxorilocalidade, Masculinidade, Guna.
ALLIANCE AS DRAMA:

ETHICS AND AESTHETICS OF MASCULINITY IN THE CONTEXT OF AN UXORILOCAL AFFECTIVE ECONOMY (GUNA, PANAMA)

\begin{abstract}
This article looks at the Guna through the prism of the residential home, a privileged space for communion and sharing scarce resources. I first show that residence in Gunayala is based on a "domestic economy of thoughts": a lazy person (wiegala) is someone who does not think of others (binsaed suli), and is thus called sunnasuli - "not a true relative" or simply "mean person". The language of the gift stamps transactions that take place in the context of intimacy. I explore the consequences of the Guna ethics of conviviality in relation to manhood, considering the thought of men towards their wives as a condition for maintaining and keeping them in the house of their affines. The issue of exchange is analysed through the mythological, ritual and sociological roots of uxorilocality, allowing us to frame the effort in consubstantializing affines in terms of residential drama: the drama of alliance or alliance as drama.
\end{abstract}

Key words: Gender, Intimacy, Ethics, Uxorilocality, Manhood, Guna. 
LA ALIANZA COMO DRAMA:

EST/ÉTICA DE LA MASCULINIDAD

EN EL CONTEXTO DE UNA

ECONOMÍA AFECTIVA UXORILOCAL

(GUNA, PANAMÁ)

\section{Resumen}

Este artículo propone observar la sociedad Guna a partir del prisma de la residencia, espacio privilegiado de comunión y de intercambio de recursos. Mi objetivo consiste en demostrar que la residencia en Guanayala está basada en una economía doméstica del pensamiento: una persona perezosa (wiegala) es considerada por los Guna como alguien que no piensa en los demás (binsaed suli), y por lo tanto, como sunnasuli, "no es un pariente verdadero" o simplemente "persona malvada". El lenguaje del don es el que se utiliza para dar cuenta de las transacciones que tienen lugar en el ámbito de la intimidad. En este artículo intento explorar las consecuencias de la ética de la convivialidad guna en relación con la masculinidad, en la medida en que los hombres piensan en sus mujeres como condición de permanencia en la casa de los afines. La problemática del intercambio es analizada a partir de las raíces mitológicas, rituales y sociológicas de la uxorilocalidad. Así se puede entender el esfuerzo de consanguinización de la afinidad en términos de un drama residencial: el drama de la alianza o la alianza como drama.

Palabras clave: Género, Intimidad, Ética, Uxorilocalidad, Masculinidad, Guna. 